\title{
Kajian Keseragaman Kualitas Pengeringan Cabai Merah Dengan Menggunakan Alat Pengering Tipe Hohenheim
}

(study the uniformity of drying quality of red peppers using hohenheim type dryers)

\author{
Edi Saputra ${ }^{1}$, Mustaqimah $^{1}$, Diswandi Nurba ${ }^{*}$ \\ ${ }^{1}$ Program Studi Teknik Pertanian, Fakultas Pertanian, Universitas Syiah Kuala
}

\begin{abstract}
Abstrak. Dari hasil penelitianpengeringan cabai merah menunjukkan bahwa pada perlakuan tanpa blansir terdapat suhu rata-rata dalam ruang alat pengering pada hari pertama yaitu sebesar $54^{\circ} \mathrm{C}$ dan pada hari kedua yaitu sebesar $46,6^{\circ} \mathrm{C}$,sedangkan suhu rata-rata pada perlakuan diblansir yaitu sebesar $58,6^{\circ} \mathrm{C}$. Kelembaban relatif rata-rata dala ruang alat pengering pada perlakuan tanpa blansir pada hari pertama yaitu sebesar $40,2 \%$ dan kelembaban relatif rata-rata pada hari kedua yaitu sebesar 51\%, sedangkan kelembaban relatif rata-rata pada perlakuan di blansir yaitu sebesar $35,7 \%$. Kadar air akhir pada cabai merah kering dengan perlakuan tanpa blansir yaitu $\mathrm{P}_{1}=9,84 \%, \mathrm{P}_{2}=10,50 \%, \mathrm{P}_{3}=10,06 \%, \mathrm{P}_{4}=9,84 \%, \mathrm{P}_{5}=10,28 \%$ dan $\mathrm{P}_{6}=9,62 \%$. Sedangkan Kadar air akhir pada cabai merah kering dengan perlakuan diblansir yaitu $P_{1}=9,74 \%, P_{2}=9,74 \%, \quad P_{3}=10,36 \%$, $\mathrm{P}_{4}=10,15 \%, \mathrm{P}_{5}=9,74 \%$ dan $\mathrm{P}_{6}=9,53 \%$. Kandungan vitamin $\mathrm{C}$ didapat pada cabai merah kering dengan perlakuan tanpa blansir yaitu $\mathrm{P}_{1}=39,33 \%, \mathrm{P}_{2}=43 \%, \mathrm{P}_{3}=45,6 \%, \mathrm{P}_{4}=44,93 \%, \mathrm{P}_{5}=41,27 \%$ dan $\mathrm{P}_{6}=37,73 \%$. Sedangkan kandungan vitamin $\mathrm{C}$ akhir pada cabai merah kering dengan perlakuan diblansir yaitu $\mathrm{P}_{1}=34,13 \%$, $\mathrm{P}_{2}=37,4 \%, \mathrm{P}_{3}=40,8 \%, \quad \mathrm{P}_{4}=38,87 \%, \mathrm{P}_{5}=36,07 \%$ dan $\mathrm{P}_{6}=33,36 \%$.Uji organoleptik Cabai merah kering menunjukkan bahwa panelis lebih banyak menyukai dengan perlakuan diblansir.
\end{abstract}

Kata Kunci : Cabai merah, Pengeringan, Hohenheim

\begin{abstract}
Abstrack.From the results of red pepper cultivation research showed that on treatment without blancing there is average temperature in the dryer room on the first day that is equal to $54 \%{ }^{\circ} \mathrm{C}$ and on the second day that is equal to $46,6^{\circ} \mathrm{C}$, while the average temperature at the blancing treatment that is equal to $58,6^{\circ} \mathrm{C}$. The average relative humidity in the drying chamber on the bluffing treatment on the first day is $40,2 \%$ and the average relative humidity on the second day is $51 \%$, while the average relative humidity at the blancing treatment is $35,7 \%$. The final water content of dried red pepper with bluff treatment is $\mathrm{P} 1=9,84 \%, \mathrm{P} 2=10,50 \%, \mathrm{P} 3=10,06 \%, \mathrm{P} 4=9,84 \%$, $\mathrm{P} 5=10,28 \%$ and $\mathrm{P} 6=9,62 \%$. While the final water content of dried red pepper with blancing treatment is $\mathrm{P} 1=9,74 \%, \mathrm{P} 2=9,74 \%, \mathrm{P} 3=10,36 \%, \mathrm{P} 4=10,15 \%, \mathrm{P} 5=9,74 \%$ and $\mathrm{P} 6=9.53 \%$. The content of vitamin $\mathrm{C}$ was found in dry red chilli with the treatment without blancing that is $\mathrm{P} 1=39,33 \%, \mathrm{P} 2=43 \%, \mathrm{P} 3=45,6 \%, \mathrm{P} 4=44,93 \%$, $\mathrm{P} 5=41,27 \%$ and $\mathrm{P} 6=37,73 \%$. While the final vitamin $\mathrm{C}$ content of dried red pepper with blancing treatment is $\mathrm{P} 1=34,13 \%, \mathrm{P} 2=37,4 \%, \mathrm{P} 3=40,8 \%, \mathrm{P} 4=38,87 \%, \mathrm{P} 5=36,07 \%$ and $\mathrm{P} 6=33.36 \%$. The red pepper organoleptic test showed that the panelists preferred the treatment in blancing.
\end{abstract}

Keywords :red pepper, drying, Hohenheim

\section{PENDAHULUAN}

Tanaman cabai yang banyak dibudidayakan di Indonesia adalah cabai merah, Bagi masyarakat indonesia khususnya Aceh cabai merah merupakan bahan utama untuk berbagai jenis masakan, karena sangat tidak enak jika masakan dibuat tanpa cabai merah. Sejauh ini masih banyak petani yang mengeringkan cabai merah dengan cara tradisional, yaitu dengan cara penjemuran di bawah sinar matahari langsung sebagai sumber energi dengan hanya beralaskan terpal ataupun plastik. Pengeringan ini dilakukan secara terbuka, dimana pengeringan secara terbuka menyebabkan rawan kontaminasi dari udara dan debu dari lingkungan sekitar. Atas dasar ini, diperlukan sebuah alat pengering yang dapat membantu petani melakukan proses pengeringan yang lebih baik

Cabai merah memiliki sifat mudah rusak. Sifat mudah rusak ini dipengaruhi oleh kadar air dalam cabai yang sangat tinggi dari kandungan cabai merah itu sendiri. Hal ini dapat menjadi penyebab kerusakan cabai pada saat musim panen raya. Dikarenakan hasil panen 
yang melimpah sedangkan proses pengeringan tidak dapat berlangsung secara serentak, oleh sebab itu kadar air pada cabai masih dalam keadaan besar, sehingga menyebabkan pembusukan.

Salah satu cara mempertahankan mutu dan memperpanjang umur simpan cabai merah dengan melakukan pengeringan dengan menggunakan alat pengering, hal ini diharapkan bisa lebih memudahkan dan meringankan kerja para petani. Ketika hujan petani tidak perlu memindahkan bahan yang dijemur karena bahan yang di dalam alat pengering tidak akan gampang terganggu oleh keadaan lingkungannya. Sehingga dapat mengurangi kontaminasi dari debu, udara, dan lain sebagainya.

\section{METODE PENELITIAN}

Penelitian ini dilaksanakan pada bulan April 2016 sampai dengan bulan Oktober 2016 di halaman fakultas pertanian, di Laboratorium Pasca Panen Program Studi Teknik Pertanian dan di Laboratorium Analisis Hasil Pertanian Program Studi Teknologi Hasil Pertanian Universitas Syiah Kuala.

\section{Alat dan Bahan}

Alat yang akan digunakan dalam penelitian ini adalah satu unit alat pengering Hohenheim menggunakan energi matahari, ), water Bath, termometer, RH meter, timbangan digital, dan cawan.

Bahan baku yang digunakan dalam penelitian ini adalah cabai merah keriting sebanyak $12 \mathrm{~kg}$ dengan rincian $6 \mathrm{~kg}$ untuk perlakuan blancing dengan kadar air awal sebesar $79,6 \%$ dan $6 \mathrm{~kg}$ untuk perlakuan tanpa blancing dengan kadar air awal sebesar 78,1\%. Cabai merah di peroleh dari petani Sibreh, Kabupaten Aceh Besar.

\section{Deskripsi Alat Pengering Tipe Hohenheim}

Pengeringan cabai merah pada penelitian ini menggunakan alat pengering surya tipe Hohenheim. Alat ini berukuran dimensi $6 \times 2$ meter atau $12 \mathrm{~m}^{2}$ yang terbagi dua atas ruang pengering dan absorber atau penyerap panas dimana masing-masing berukuran $3 \times 2$ meter atau $6 \mathrm{~m}^{2}$ (Gambar 1). Absorber pada alat ini menggunakan seng bergelombang yang dicat hitam pada bagian atasnya karena penyerap panas yang ideal adalah benda hitam.Pada alat ini juga memiliki kipas 3 buah dan plastik transparan yang digunakan sebagai penutup dari alat ini.

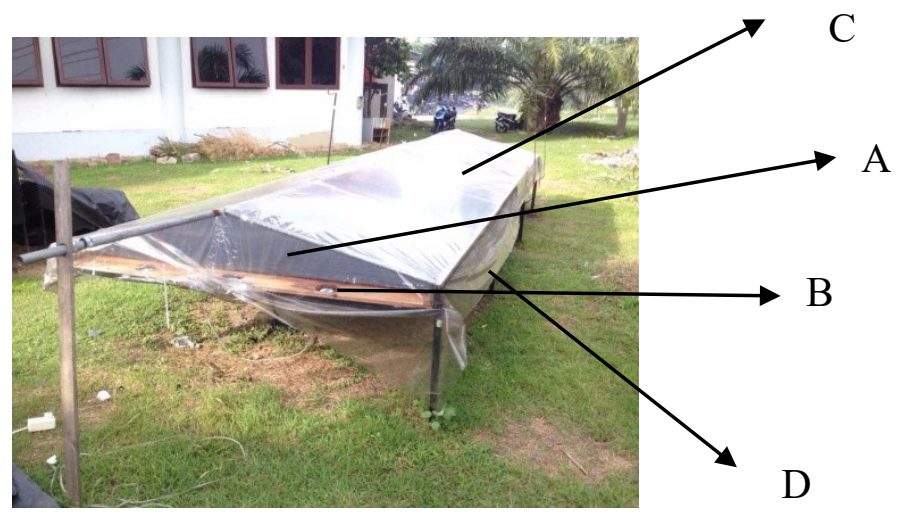

$$
\begin{aligned}
& \text { Keterangan: } \\
& A=\text { Absorber } \\
& B=\text { Kipas } \\
& C=\text { Ruang pengering } \\
& D=\text { Plastik transparan }
\end{aligned}
$$

Gambar 1. Bagian-bagian alat pengering tipe Hohenheim 


\section{HASIL DAN PEMBAHASAN}

\section{Distribusi Suhu Pengeringan Cabai merah (Capsicum annuum L)}

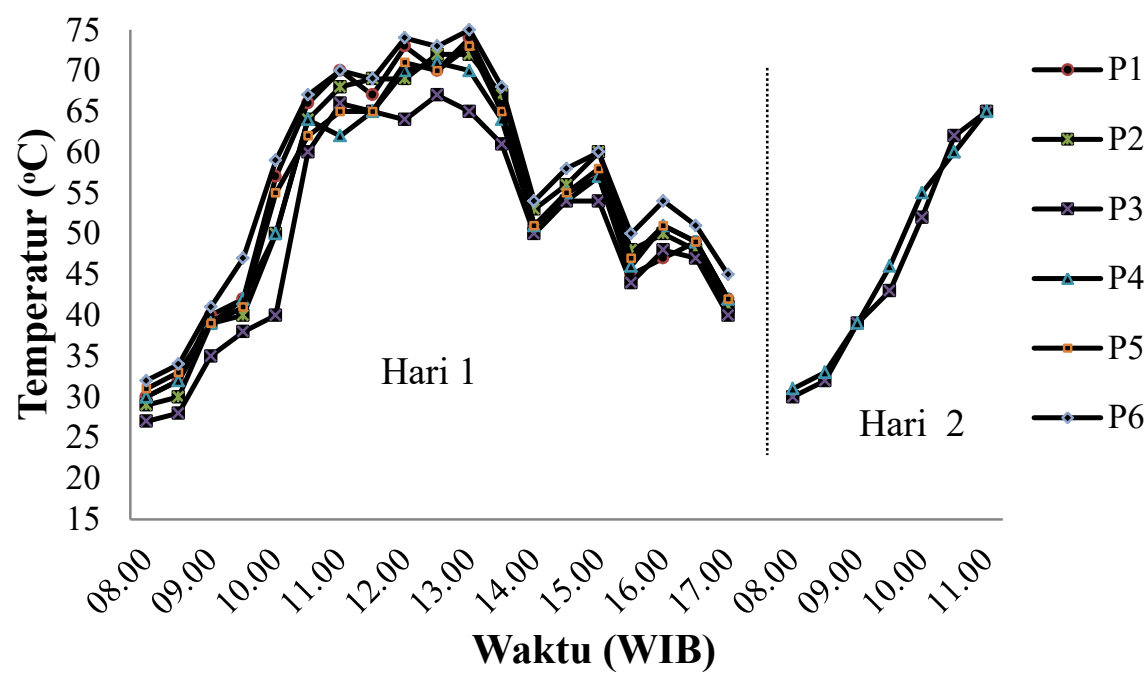

Gambar 2. Distribusi suhu pada pengeringan hari pertama dan ke dua(12 dan 13 April 2016)

Hari pertama suhu rata-rata tertinggiterdapat pada $\mathrm{P}_{6}$ yaitu sebesar $56,9^{\circ} \mathrm{C}$, yang mana suhu maksimum pada pengeringan hari pertama juga terdapat pada $\mathrm{P}_{6}$ sebesar $75^{\circ} \mathrm{C}$ pada pukul 13.00 WIB. Sedangkan suhu rata-rata terendah terdapat pada $\mathrm{P}_{3}$ sebesar $50,2^{\circ} \mathrm{C}$, yang mana suhu minimum pada pengeringan hari tersebut terdapat pada $\mathrm{P}_{3}$ sebesar $40^{\circ} \mathrm{C}$ pada pukul 17.00 WIB, Sedangkan pada hari kedua pengeringan atau pengukuran suhu hanya di lanjutkan padaP ${ }_{3}$ dan $\mathrm{P}_{4}$, ini di sebabkan kadar air yang terkandung dalam bahan sudah mencapai batas kadar air yang di inginkan yaitu $10 \%$, dengan suhu rata-rata tertinggi terdapat pada $\mathrm{P}_{4}$ yaitu sebesar $47^{\circ} \mathrm{C}$ dan suhu rata-rata terendah pada $\mathrm{P}_{3}$ sebesar $46,1^{\circ} \mathrm{C}$.

Hari ke tiga (14 April 2016) untuk pengeringan dilakukan blansir pengeringan dilakukan selama 8 jam, 4 jam lebih cepat daripada pengeringan tanpa blansir. Hal ini dikarenakan kadar air yang terkandung dalam cabai merah sudah mencapai batas standar pengeringan yaitu $10 \%$, sehingga pengeringan dihentikan.

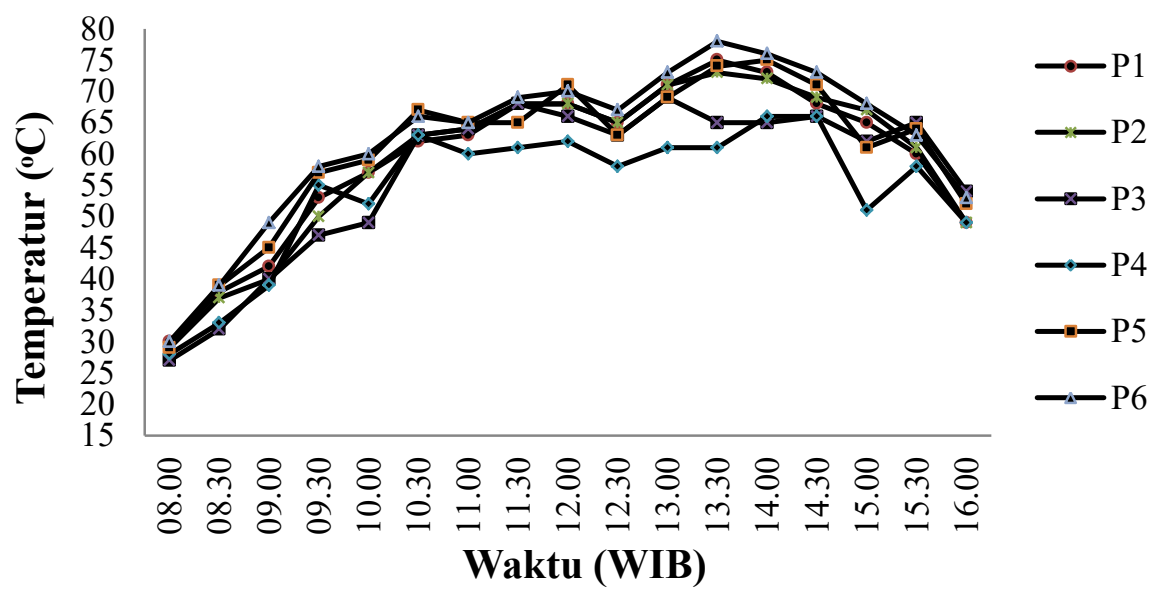

Gambar 3. Distribusi suhu pada pengeringan hari ketiga (14 April 2016) 
Dari hasil pengukuran suhu pada hari ketiga, suhu rata-rata pada $\mathrm{P}_{1}$ sebesar $59,2^{\circ} \mathrm{C}, \mathrm{P}_{2}$ sebesar $59^{\circ} \mathrm{C}, \mathrm{P}_{3}$ sebesar $56,8^{\circ} \mathrm{C}, \mathrm{P}_{4}$ sebesar $54,3^{\circ} \mathrm{C}, \mathrm{P}_{5}$ sebesar $60,4^{\circ} \mathrm{C}$, dan pada $\mathrm{P}_{6}$ sebesar $62,2^{\circ} \mathrm{C}$. Berdasarkan data tersebut, suhu rata-rata yang tertinggi terdapat pada $\mathrm{P}_{6}$ yaitu sebesar $62,2^{\circ} \mathrm{C}$, yang mana suhu maksimum pada pengeringan hari ke-3 juga terdapat pada $\mathrm{P}_{6}$ sebesar $78^{\circ} \mathrm{C}$ pada pukul 13.30 WIB. Sedangkan suhu rata-rata terendah terdapat pada $\mathrm{P}_{4}$ yaitu sebesar $54,3^{\circ} \mathrm{C}$, yang mana suhu minimum pada pengeringan hari ini terdapat pada $\mathrm{P}_{3}$ sebesar $27^{\circ} \mathrm{C}$ pada pukul 08.00 WIB.

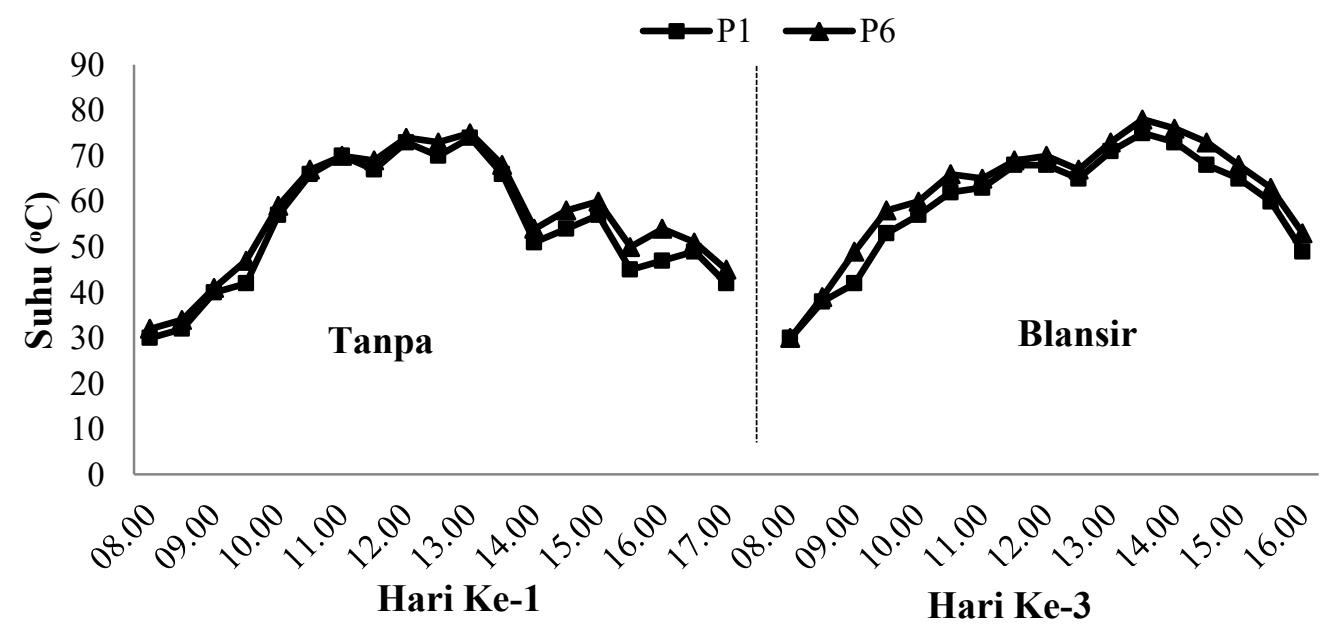

Gambar 4. Suhu pada $\mathrm{P}_{1}$ dan $\mathrm{P}_{6}$ yang berjarak 0 meter dari absorber

Berdasarkan Gambar di atas, dapat dilihat perbandingan suhu $\mathrm{P}_{1}$ dan $\mathrm{P}_{6}$ yang merupakan titik pengeringan pada jarak 0 meter dari absorber pada pengeringan hari pertama dan hari ketiga. Hasil pengukuran menunjukkan bahwa rata-rata suhu $\mathrm{P}_{1}$ dan $\mathrm{P}_{6}$ pada pengeringan hari pertama lebih rendah daripada pengeringan hari ketiga, dimana ratarata suhu $\mathrm{P}_{1}$ dan $\mathrm{P}_{6}$ hari pertama sebesar $55,6^{\circ} \mathrm{Cdan}$ pada hari ketiga yaitu sebesar $60,7^{\circ} \mathrm{C}$. Pada pengeringan hari pertama rata-rata suhu pada $\mathrm{P}_{6}$ lebih tinggi daripada $\mathrm{P}_{1}$, dimana ratarata suhu pada $\mathrm{P}_{6}$ sebesar $56,9^{\circ} \mathrm{C}$ dan pada $\mathrm{P}_{1}$ sebesar $54,3^{\circ} \mathrm{C}$. Sedangkan pada pengeringan hari ketiga rata-rata suhu pada $\mathrm{P}_{6}$ sebesar $62,2^{\circ} \mathrm{C}$ lebih tinggi daripada $\mathrm{T}_{1}$ yaitu sebesar $59,2^{\circ} \mathrm{C}$.

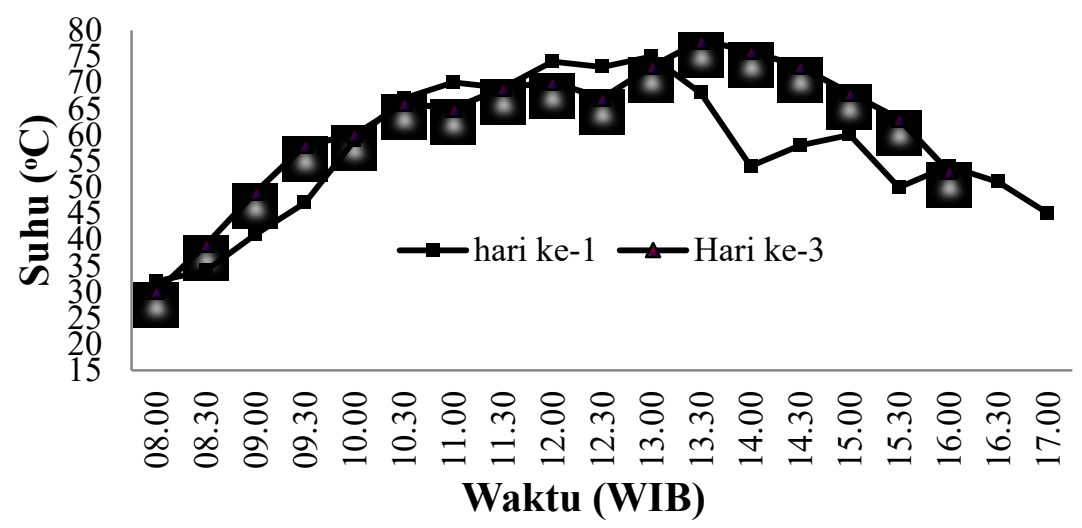

Gambar 5. Suhu $\mathrm{P}_{6}$ pada pengeringan hari pertama dan pengeringan hari ketiga. 
Pada ketiga hari pengeringanyaitu pengeringan hari pertama dan pengeringan hari ketiga, suhu rata-rata tertinggi terdapat pada $\mathrm{P}_{6}$. Nilai suhu $\mathrm{P}_{6}$ pada pengeringan hari pertama dan padapengeringan hari ketiga dapat dilihat pada Gambar 5. Berdasarkan Gambar 5, suhu $\mathrm{P}_{6}$ pada pukul $10.00 \mathrm{WIB}$ pada pengeringan hari pertama danpengeringan hari ketiga hanya memiliki perbedaan $1{ }^{\circ} \mathrm{C}$. Suhu $\mathrm{P}_{6}$ pukul $10.00 \mathrm{WIB}$ pada pengeringan hari pertama sebesar $59^{\circ} \mathrm{C}$, sedangkan pada pengeringan hari ketiga sebesar $60^{\circ} \mathrm{C}$. Namun nilai suhu rata-rata $\mathrm{P}_{6}$ pada pengeringan hari ketiga lebih tinggi daripada pengeringan hari pertama, dimana suhu rata-rata pada pengeringan hari ketiga sebesar $62,2^{\circ} \mathrm{C}$ dan pada pengeringan hari pertama sebesar $56,9^{\circ} \mathrm{C}$.

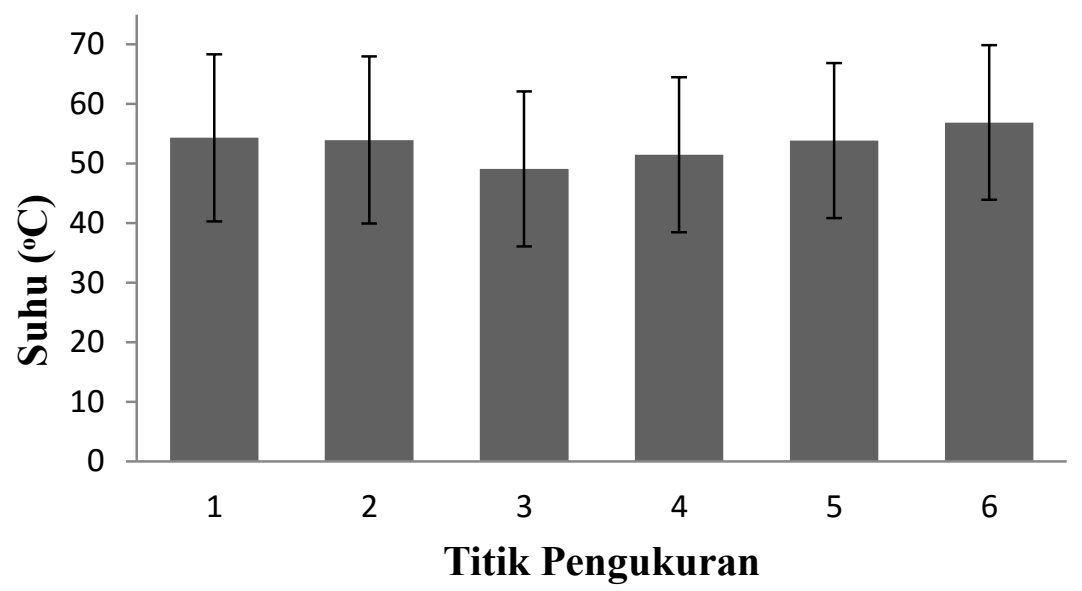

Gambar 6. Suhu rata-rata hari pertama dan kedua (tanpa blansir)

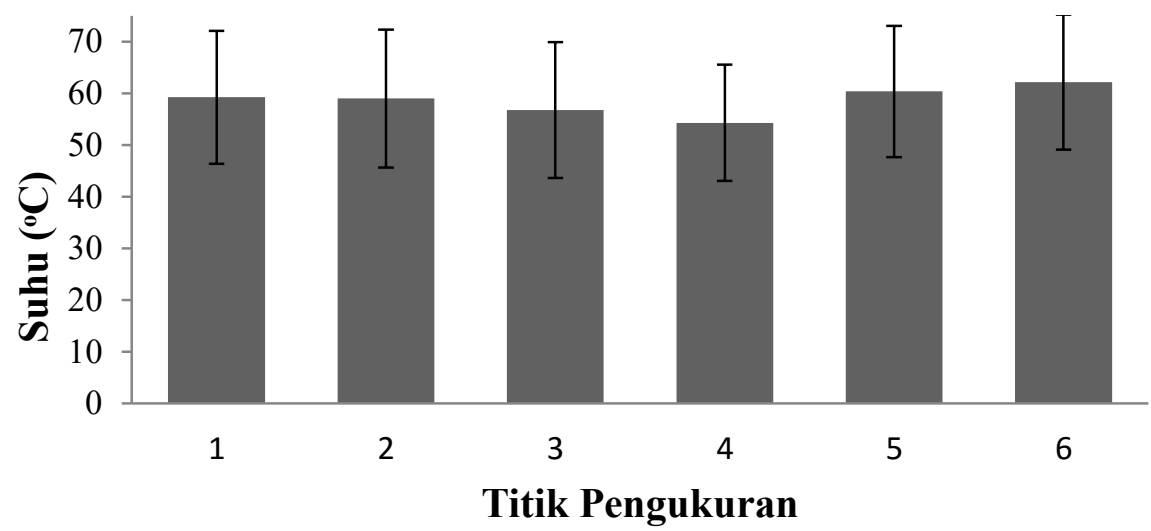

Gambar 7. Suhu rata-rata hari ke tiga (diblansir)

Pengering tanpa blansir selama 2 hari pengeringan menghasilkan suhu maksimum sebesar $75^{\circ} \mathrm{C}$ pada hari pertama (12April 2016) dan sebesar $65^{\circ} \mathrm{C}$ pada hari kedua (13April 2016). Sedangkan suhu pada ruang pengering diblansir menghasilkan suhu maksimum sebesar $78^{\circ} \mathrm{C}$ pada hari ketiga (14April 2016). Dihasilkan rata-rata suhu tertinggi pengeringan tanpa blancing hari pertama dan hari kedua terdapat pada $\mathrm{P}_{6}$ yaitu sebesar $56,9^{\circ} \mathrm{C}$. Sedangkan ratarata suhu tertinggi pengeringan diblansir pada hari ke tiga juga terdapat pada $\mathrm{P}_{6}$ yaitu sebesar $62,2^{\circ} \mathrm{C}$. Rata-rata suhu terendah pada hari pertama dan hari kedua terdapat pada $\mathrm{P}_{3}$ sebesar $49,1^{\circ} \mathrm{C}$, Sedangkan Rata-rata suhu terendah pada hari ketiga terdapat pada $\mathrm{P}_{4}$ sebesar $54,3^{\circ} \mathrm{C}$. Perbedaan yang terjadi selama 3 hari pengeringan tersebut dikarenakan 
kondisi cuaca dan suhu lingkunganselama 3 hari ini berbeda, karena kondisi alam selalu berubah-ubah.

Semakin tinggi suhu yang digunakan untuk pengeringan, maka makin cepat pula laju pengeringan.Namun menurut Taib et al. (1988), suhu yang terlalu tinggi harus diwaspadai karena dapat merusak bahan, yakni permukaan bahan terlalu cepat kering, sehingga tidak sebanding dengan kecepatan pergerakan air bahan ke permukaan.

\section{Distribusi Kelembaban Relatif Pengeringan Cabai merah (Capsicum annuum L)}

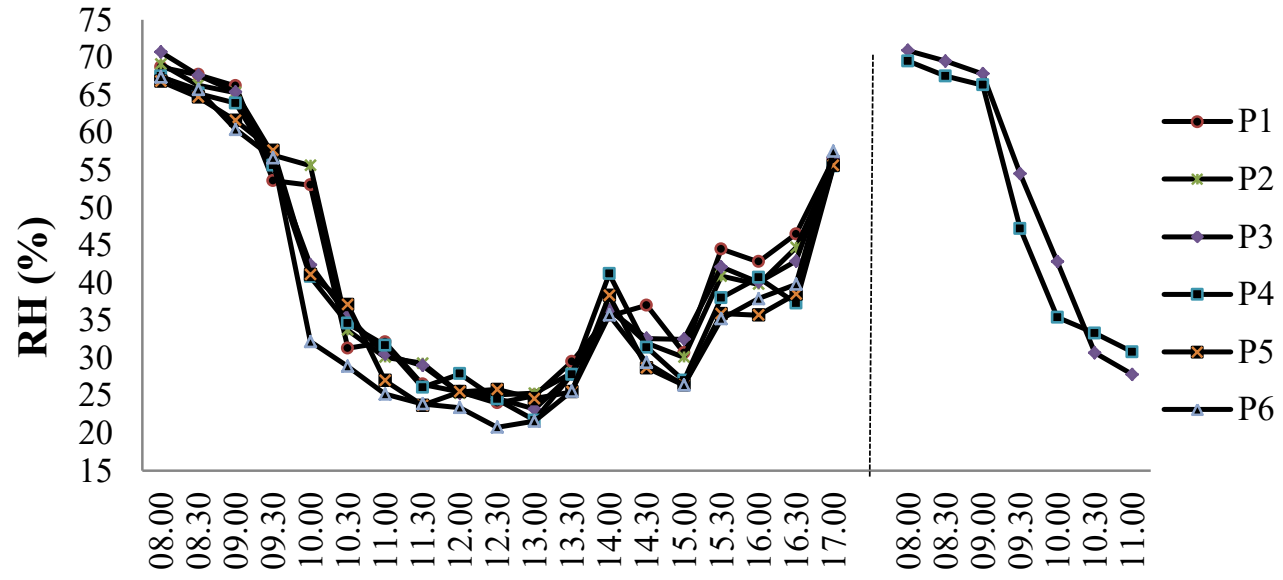

Waktu (WIB)

Gambar 8. Distribusi RH pada pengeringan hari pertama dan kedua(12 dan 13 April 2016)

RH rata-rata tertinggi terdapat pada $\mathrm{P}_{3}$ sebesar $44 \%$, dimana $\mathrm{RH}$ maksimum yangpada pengeringan tanpa blansir hari pertama juga terdapat pada $\mathrm{P}_{3}$ yaitu sebesar $70,7 \%$ dan pada hari ke dua juga terdapat pada $\mathrm{P}_{3}$ yaitu sebesar 70,9\% yang terjadi pada pukul 08.00 WIB. Sedangkan $\mathrm{RH}$ rata-rata terendah terdapat pada $\mathrm{P}_{6}$ sebesar 37,6\%, dimana $\mathrm{RH}$ minimum yang terjadi selama pengeringan hari pertama dan ke dua terdapat pada $\mathrm{P}_{6}$ sebesar $20,8 \%$ yang terjadi pada pukul 12.30 WIB.

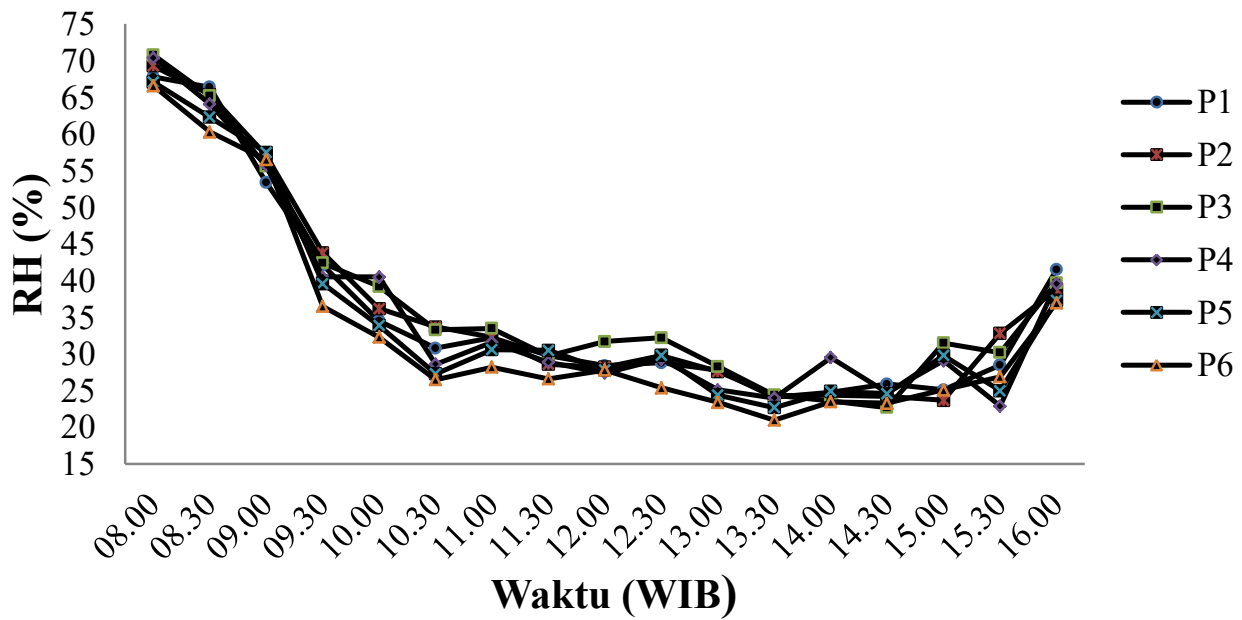

Gambar 9. Distribusi RH pada pengeringan hari ketiga (14 April 2016 )

Pengambilan data RH pada hari ketiga (14 April 2016) pengeringan dengan blansir, pengambilan data dilakukan selama 30 menit sekali, sama dengan pengambilan data pada hari 
pertama dan kedua. Hasil pengukuran RH pada hari ketiga dapat dilihat pada Gambar 12 . Pada hari ketiga (14 April 2016), RH rata-rata pada $\mathrm{P}_{1}$ sebesar $36 \%, \mathrm{P}_{2}$ sebesar $36,5 \%, \mathrm{P}_{3}$ sebesar 37,2\%, $\mathrm{P}_{4}$ sebesar $36 \%, \mathrm{P}_{5}$ sebesar $35 \%$, dan $\mathrm{P}_{6}$ sebesar 33,3\%.RH rata-rata tertinggi pada hari ketiga terdapat pada $\mathrm{P}_{3}$ sebesar $37,3 \%$, dimana $\mathrm{RH}$ maksimum pada hari tersebut terdapat pada $\mathrm{P}_{3}$ sebesar $70,8 \%$ yang terjadi pada pukul 08.00 WIB. Sedangkan RH rata-rata terendah terdapat pada $\mathrm{P}_{6}$ sebesar 33,3\%, dimana $\mathrm{RH}$ minimumnya terdapat pada $\mathrm{P}_{6}$ sebesar $21 \%$ yang terjadi pada pukul $13.30 \mathrm{WIB}$.

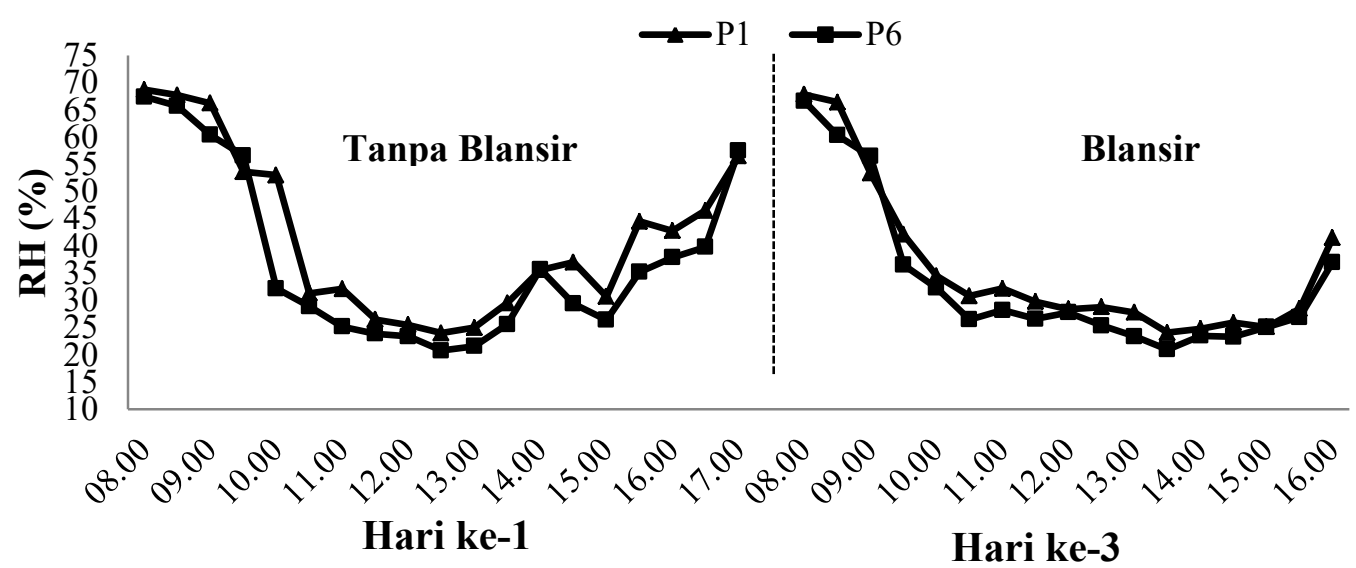

Gambar 10. $\mathrm{RH}$ pada $\mathrm{P}_{1}$ dan $\mathrm{P}_{6}$ yang berjarak 0 meter dari absorber

Hasil pengukuran menunjukkan bahwa rata-rata kelembaban relatif $\mathrm{P}_{1}$ dan $\mathrm{P}_{6}$ padapengeringan hari pertama lebih tinggi daripada pengeringan hari ketiga, dimana rata-rata kelembaban relatif $\mathrm{P}_{1}$ dan $\mathrm{P}_{6}$ pada pengeringan hari pertama sebesar $39,75 \%$, dan pengeringan hari ketiga yaitu sebesar 34,65\%. Pada pengeringan hari pertama, rata-rata kelembaban relatif pada $\mathrm{P}_{1}$ sedikit lebih tinggi daripada $\mathrm{P}_{6}$, dimana rata-rata kelembaban relatif pada $\mathrm{P}_{1}$ sebesar $41,9 \%$, dan pada $\mathrm{P}_{6}$ sebesar 37,6\%. Sedangkan pada pengeringan hari ketiga, rata-rata kelembaban relatif pada $\mathrm{P}_{1}$ juga masih lebih tinggi daripada $\mathrm{P}_{6}$, dimana ratarata kelembaban relatif pada $\mathrm{P}_{1}$ sebesar $36 \%$ dan pada $\mathrm{P}_{6}$ sebesar $33,3 \%$.

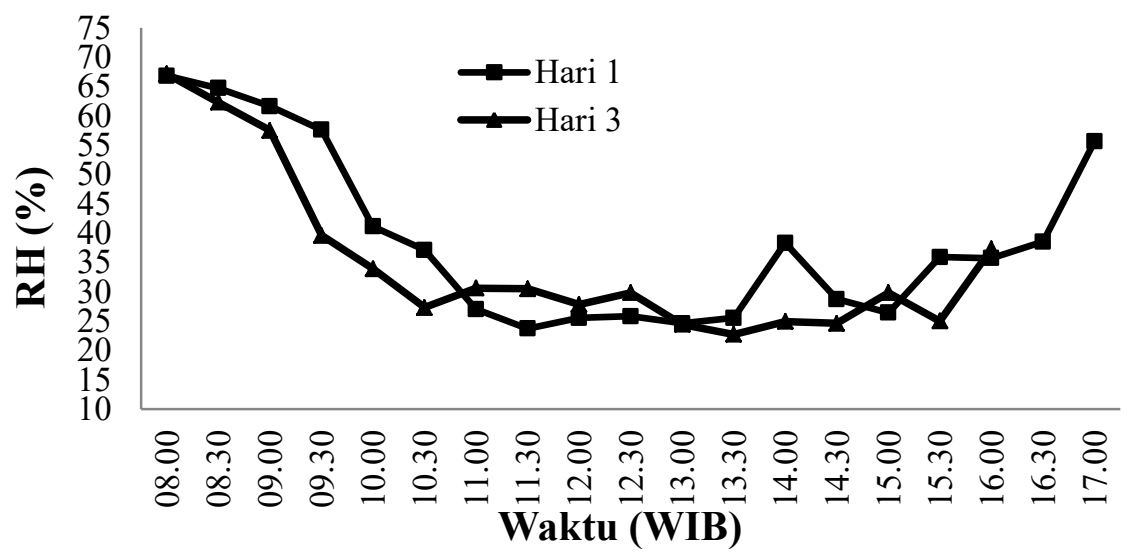

Gambar 11.Kelembaban relatif pada $\mathrm{P}_{5}$ terhadap pengeringan hari pertama dan pengeringan hari ketiga.

Berdasarkan Gambar 11, nilai RH pada $\mathrm{P}_{5}$ pada pukul 09.30 WIB pada pengeringan hari pertama dan pengeringan hari ketiga memiliki perbedaan sebesar $18 \%$ sedikit lebih jauh 
di bandingkan dengan yang lain. Selanjutnya memiliki nilai RH yang berbeda tidak terlalu jauh perbedaan pada jam berikutnya, kecuali pada pukul 13.00 WIB yang memiliki kesamaan kelembaban yaitu $24 \%$. RH pada $\mathrm{P}_{5}$ pukul $10.00 \mathrm{WIB}$ pada pengeringan hari pertama sebesar $41,1 \%$, sedangkan pada pengeringan hari ketiga sebesar 33,9\%. Nilai $\mathrm{RH}$ rata-rata $\mathrm{P}_{5}$ pada pengeringan hari pertama lebih tinggi daripada pengeringan hari ketiga, dimana RH rata-rata pada pengeringan hari pertama sebesar $39 \%{ }^{\circ} \mathrm{C}$ dan pada pengeringan hari ketiga sebesar $35 \%$.

Dari hasil perbandingan $\mathrm{RH}$ rata-rata pada ketiga hari pengeringan di atas menunjukkan bahwa kelembaban yang terjadi pada ruang pengering mendapatkan hasil perbandingan yang tidak jauh berbeda dengan hari pertama, kedua dan ketiga. Perbedaan yang terjadi selama 3 hari pengeringan tersebut di sebabkan karna kondisi alam hari ke hari yang selalu berubah-ubah.

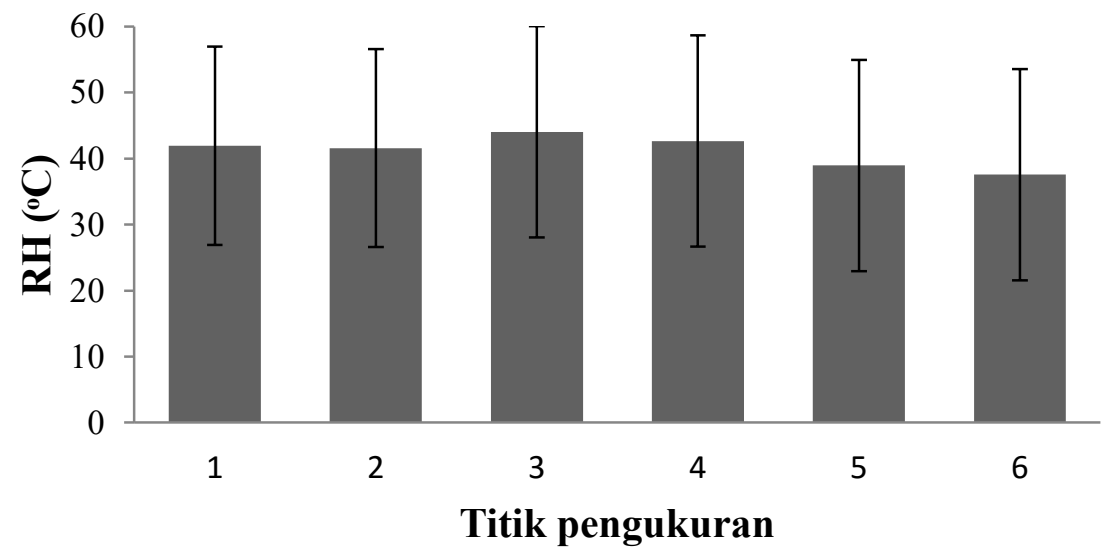

Gambar 12. RH rata-rata hari pertama dan kedua (tanpa blancing)

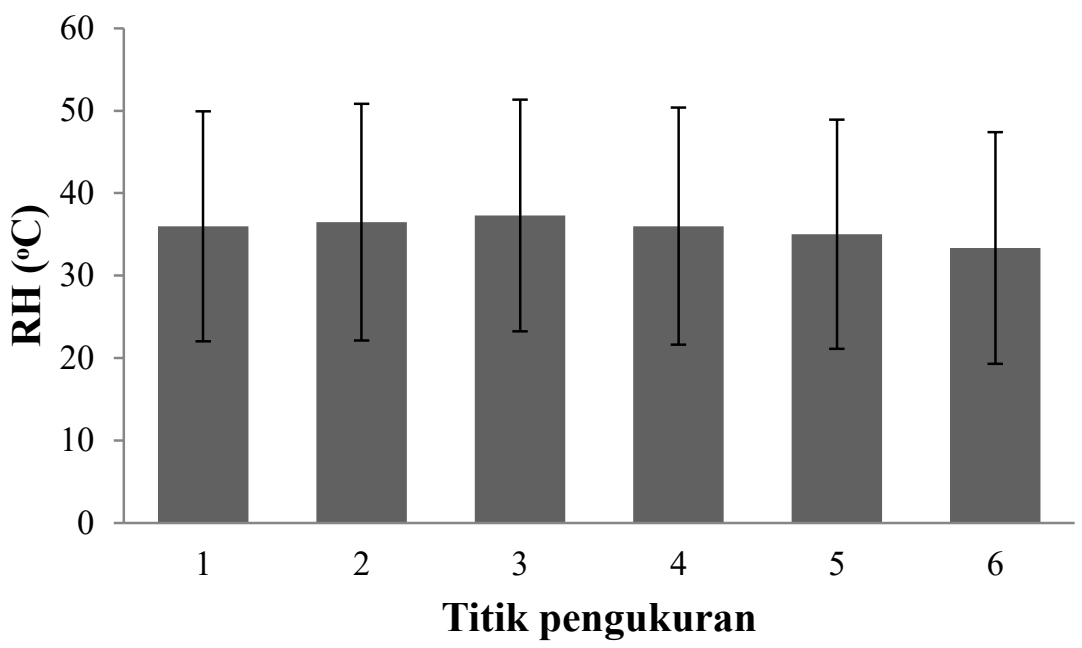

Gambar 13. RH rata-rata hari ketiga (diblansir)

Pada penelitian ini dihasilkan rata-rata kelembaban relatif pada pengeringan hari pertama dan kedua tanpa di blansir sebesar $41,2 \%$ dan pada hari ketiga pengeringan di blansir menghasilkan rata-rata kelembaban sebesar 35,7\%. Rata-rata kelembaban relatif tertinggi pada hari pertama dan kedua terdapat pada $\mathrm{P}_{3}$ dan $\mathrm{P}_{4}$ yang merupakan titik pengeringan pada jarak 2 meter dari absorber sebesar 44,4\% dan 42,6\%. Sedangkan rata-rata kelembaban relatif terendah pada hari pertama dan kedua terdapat pada $\mathrm{P}_{6} \mathrm{yang}$ merupakan titik pengeringan 
pada jarak 0 meter sebesar 37,6\%. Rata-rata kelembaban relatif tertinggi pada hari ketiga terdapat pada $\mathrm{P}_{3}$ yang juga merupakan titik pengeringan pada jarak 2 meter dari absorber yaitu sebesar $37,3 \%$. Sedangkan rata-rata kelembaban relatif terendah pada hari ketiga terdapat pada $\mathrm{P}_{6}$ yangmerupakan titik pengeringan pada jarak 0 meter dari absorber yaitu sebesar $33,3 \%$.s

\section{Perubahan Berat Cabai merah (Capsicum annuum L) Selama Pengeringan}

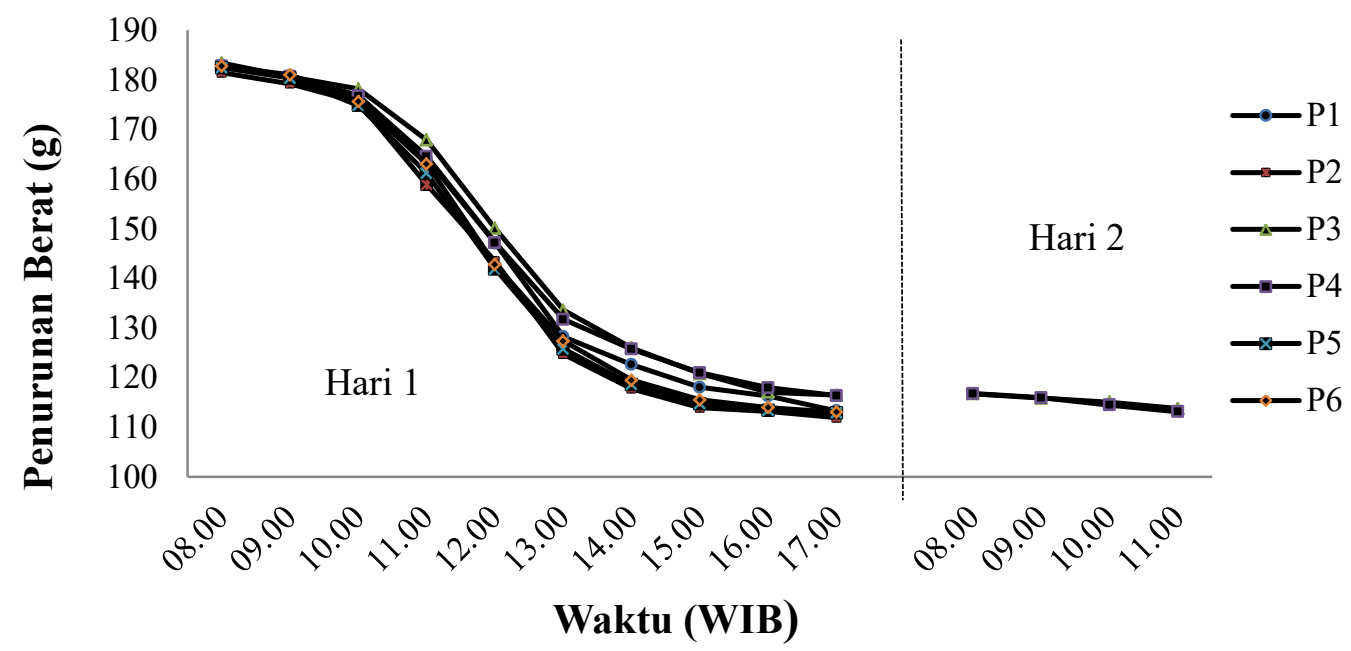

Gambar 14. Penurunan berat Cabai merah (Capsicum annuum L) pada hari pertama dan kedua (12 dan 13 April 2016)

Pada hari pertama (12April 2016) pengeringan dilakukan sampai pukul $17.00 \mathrm{WIB}$ yang kemudian akan dilanjutkan pada hari kedua hanya di lanjutkan untuk, $\mathrm{P}_{3}$ dan , $\mathrm{P}_{4}$,pengukuran berat hanya sampai pukul 11.00 WIB ini di sebabkan kadar air yang terkandung dalam bahan sudah mencapai batas standar.Masing-masing berat sampel bahan hingga akhir pengeringan hari pertama pada $P_{1}$ sebesar 113,25 gram, $P_{2}$ sebesar 111,90 gram, $\mathrm{P}_{3}$ sebesar 116,40 gram, $\mathrm{P}_{4}$ sebesar 116,35 gram, $\mathrm{P}_{5}$ sebesar 112,85 gram, dan pada $\mathrm{P}_{6}$ sebesar 113 gram. Selanjutnya untuk hari kedua bobot sampel bahan hingga akhir pengeringan pada $\mathrm{P}_{3}$ sebesar 113,75 gram, dan pada $\mathrm{P}_{4}$ sebesar 113,10 gram.

Pada pengeringan hari pertama, penurunan bobot bahan pada $P_{1}$ sebesar 69,65 gram, $P_{2}$ sebesar 69,50 gram, $\mathrm{P}_{3}$ sebesar 66,95 gram, $\mathrm{P}_{4}$ sebesar 66,40 gram, $\mathrm{P}_{5}$ sebesar 69,55 gram, dan $\mathrm{P}_{6}$ sebesar 69,70 gram. Dari hasil perhitungan tersebut, penurunan berat bahan tertinggi terdapat pada $\mathrm{P}_{6}$ yaitu sebesar 69,70 gram, sedangkan terendah terdapat pada $\mathrm{P}_{4}$ yaitu sebesar 66,40 gram. Pada hari ke dua, penurunan bahan $\mathrm{P}_{3}$ sebesar2,95 gram dan $\mathrm{P}_{4}$ sebesar 3,65 gram.

Setelah 2 hari pengeringan pada pengeringan tanpa blansir didapatlah nilai berat akhir setiap sampel bahan. Pada $\mathrm{P}_{1}$ berat akhirnya yaitu sebesar 113,25 gram, $\mathrm{P}_{2}$ sebesar 111,90 gram, $\mathrm{P}_{3}$ sebesar 113,75 gram, $\mathrm{P}_{4}$ sebesar 113,10 gram, $\mathrm{P}_{5}$ sebesar 112,85 gram, dan $\mathrm{P}_{6}$ sebesar 113 gram. Kemudian dapat dilihat juga seberapa besar perubahan berat bahan pada setiap sampel, dimana pada $\mathrm{P}_{1}$ terjadi perubahan berat sebesar 69,65 gram, $\mathrm{P}_{2}$ sebesar 69,50 gram, $\mathrm{P}_{3}$ sebesar 69,60 gram, $\mathrm{P}_{4}$ sebesar 69,65 gram, $\mathrm{P}_{5}$ sebesar 69,55 gram, dan pada $\mathrm{P}_{6}$ sebesar 69,70 gram. 


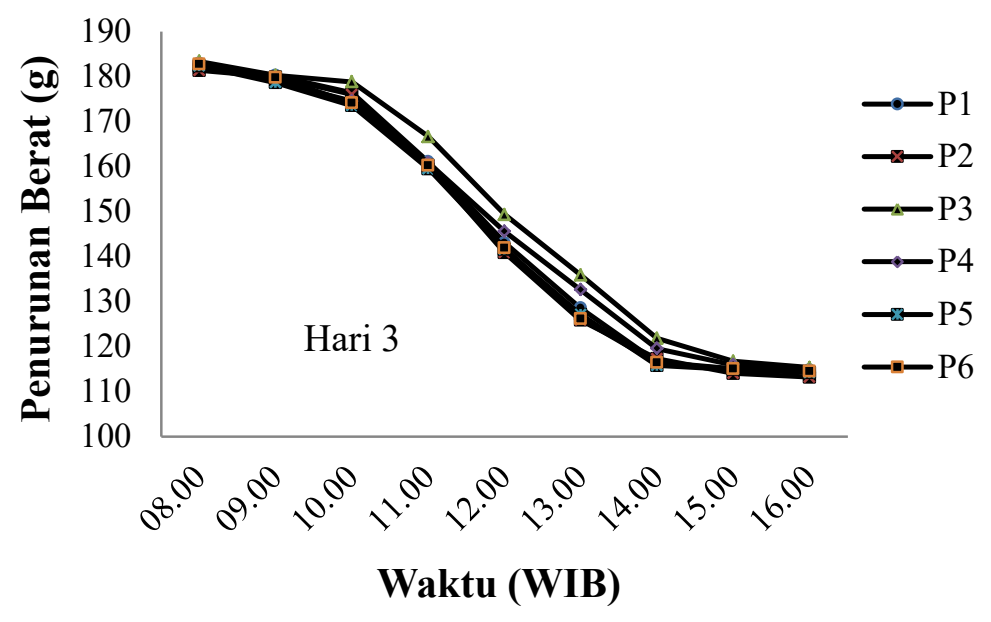

Gambar 15. Penurunan berat Cabai merah pada hari ketiga (14 April 2016)

Pada pengeringan hari ketiga, penurunan berat bahan pada $\mathrm{P}_{1}$ sebesar68,15 gram, $\mathrm{P}_{2}$ sebesar 68,15gram, $\mathrm{P}_{3}$ sebesar 68 gram, $\mathrm{P}_{4}$ sebesar 68,05 gram, $\mathrm{P}_{5}$ sebesar 68,15 gram, dan $\mathrm{P}_{6}$ sebesar 68,20 gram. Dari hasil perhitungan tersebut, penurunan berat bahan tertinggi terdapat pada $\mathrm{P}_{6}$ yaitu sebesar 68,20 gram, sedangkan terendah terdapat pada $\mathrm{P}_{3}$ yaitu sebesar 68 gram.

\section{Kadar Air Cabai merah}

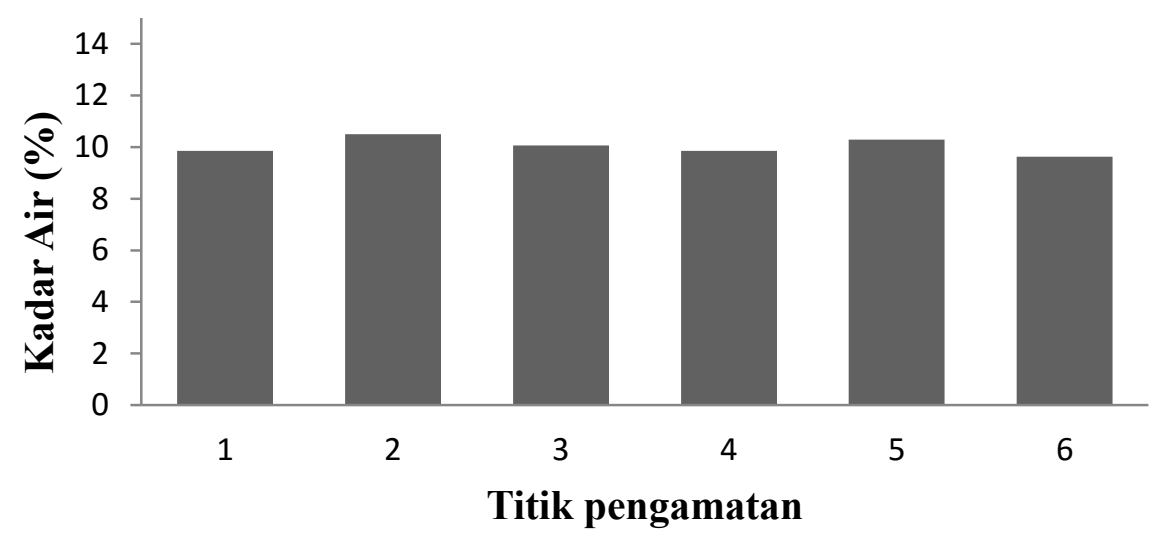

Gambar 16.Kadar air cabai merah tanpa blancing pada berbagai titik pengamatan.

Berdasarkan Gambar di atas, dapat kita lihat bahwa nilai kadar air akhir pada setiap cabai merah berbeda-beda. Pengeringan selama 2 hari menghasilkan kadar air akhir cabai merah pada titik 1 sebesar 9,84\%, titik 2 sebesar 10,50\%, titik 3 sebesar 10,06\%, titik 4 sebesar 9,84\%, titik 5 sebesar 10,28\%, dan titik 6 sebesar 9,62\%. Kadar air tertinggi terdapat pada titik 2 yaitu sebesar $10,50 \%$. Sedangkan kadar air terendah terdapat pada titik 6 yaitu sebesar $9,62 \%$. 


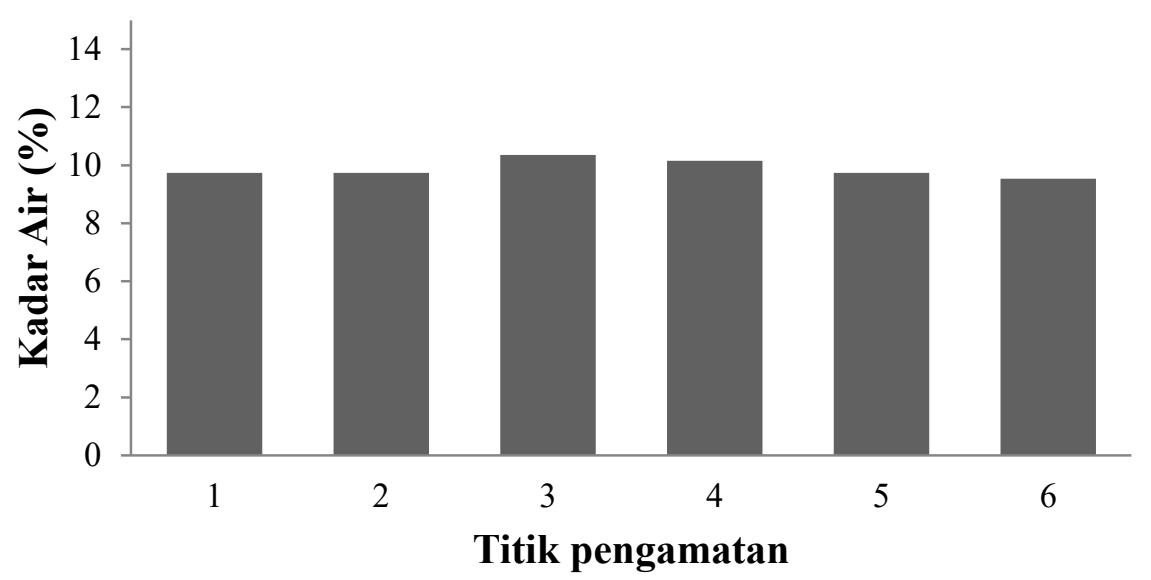

Gambar 17. Kadar air cabai merah di blancing pada berbagai titik pengamatan.

Kadar air awal Cabai merah di blansir sebesar 78,1\%.Selama pengeringan terjadi penurunan kadar air rata-rata menjadi 9,87\%.Kadar air akhir pada setiap titikberbeda-beda. Selama pengeringan menghasilkan kadar air akhir cabai merah pada titik 1 sebesar 9,74\%, titik 2 sebesar 9,74\%, titik 3 sebesar 10,36\%, titik 4 sebesar 10,15\%, titik 5 sebesar 9,74\%, dan titik 6 sebesar 9,53\%. Kadar air tertinggi terdapat pada titik 3 yaitu sebesar 10,36\%. Sedangkan kadar air terendah terdapat pada titik 6 yaitu sebesar 9,53\%.

Dari awal pengeringan terjadi penurunan kadar air lebih tinggi daripada jam berikutnya, seperti yang dinyatakan oleh Kakomole (2012), hal ini disebabkan air yang menguap adalah air bebas, setelah itu penurunan kadar air akan menurun seiring berkurangnya kadar air bahan.

\section{Vitamin C}

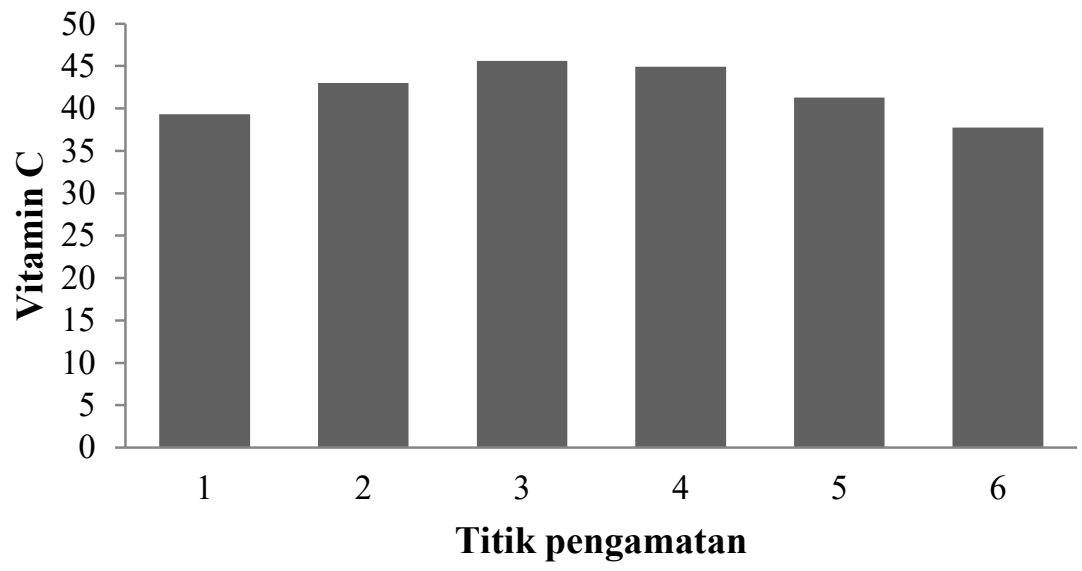

Gambar 18.Kandungan vitamin C pada pengeringan metode tanpa blancing. 


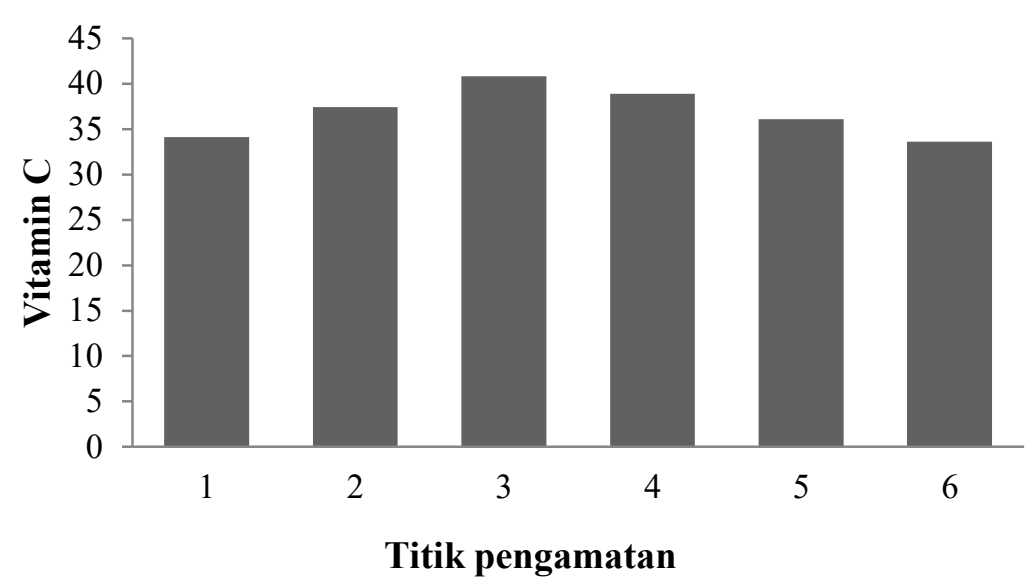

Gambar 19. Kandungan vitamin C pada pengeringan metode blansir.

Berdasarkan Gambar 18 dan Gambar 19, kandungan vitamin C pada setiap kedua metode pengeringan adalah berkisaran antara 33-45,6 mg/100 gram. Kandungan vitamin $\mathrm{C}$ maksimum didapat pada pengeringan metode tanpa blansir yaitu pada titik pengamatan $\mathrm{P}_{3}$ sebesar 45,6 mg/100gram, sedangkan kandungan vitamin $\mathrm{C}$ minimum didapat pada metode pengeringan diblansing yaitu pada titik pengamatan , $\mathrm{P}_{6}$ sebesar 33,6 mg/100gram. Hal ini dikarenakan pada metode pengeringan diblansir adanya faktor-faktor yang menyebabkan kerusakan pada vitamin $\mathrm{C}$ yaitu lama perendaman dalam air, pemanasan dalam waktu lama, dan pemanasan dalam alat yang terbuat dari besi atau tembaga.

Hasil dari penelitian menunjukkan bahwa kandungan vitamin $\mathrm{C}$ mengalami penurunan yang berbeda-beda pada pengeringan tanpa blansir dan diblansir ini dikarenakan adanya beberapa faktor yang menyebabkan kerusakan pada vitamin $\mathrm{C}$ yaitu diantaranya perlakuan blansir dan pengeringan, hal ini sesuai dengan penyataan Almatsier (2001), bahwa vitamin C mudah larut dalam air dan mudah rusak akibat pemanasan. Vitamin $\mathrm{C}$ cukup stabil dalam keadaan kering dan dalam larutan asam, namun tidak stabil dalam larutan alkali.

\section{Organoleptik}

Tabel 1. Uji organoleptik

\begin{tabular}{|c|c|c|c|c|c|c|}
\hline \multirow{2}{*}{ Pengamatan } & \multicolumn{2}{|c|}{ Warna } & \multicolumn{2}{|c|}{ Aroma } & \multicolumn{2}{|c|}{ Tekstur } \\
\hline & Angka & Nilai & Angka & Nilai & Angka & Nilai \\
\hline TBL & 8 & $\begin{array}{l}\text { Agak } \\
\text { suka }\end{array}$ & 4 & $\begin{array}{c}\text { Netral } \\
\text { Agak }\end{array}$ & 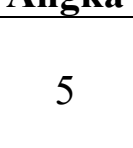 & $\begin{array}{l}\text { Agak } \\
\text { suka }\end{array}$ \\
\hline BL & 6 & Suka & 5 & suka & 6 & Suka \\
\hline
\end{tabular}

Pada Tabel di atas, dapat kita lihat hasil analisa sensori pada tiap-tiap sampel cabai merah kering memiliki perbedaan pada atributnya. Pada sampel TBL, untuk kategori warna dan tekstur panelis memberikan penilaian Agak suka (5), untuk kategori aroma panelis memberikan penilaian netral (4). Pada sampel BL, untuk kategori warna dan tekstur panelis memberikan penilaian suka (6), untuk kategori aroma panelis memberikan penilaian yaitu agak suka (5). 


\section{KESIMPULAN DAN SARAN}

Pengeringan dengan menggunakan alat pengering tipe Hohenheimini cukup efektif, dikarenakan distribusi suhu dan RH selama pengeringan relatif cukup merata. Hasil penelitian menunjukkan bahwa keseragaman kualitas cabai merah yang dikeringkan dengan alat pengering tipe Hohenheim sudah seragam.

Adapun saran yang dapat ditambahkan untuk penelitian ini, yaitu perlu dilakukan penelitian lanjutan dengan meningkatkan kecepatan kipas dalam ruang alat pengering agar dapat meningkatkan keseragaman kualitas hasil pengeringan.

\section{DAFTAR PUSTAKA}

Almatsier, S. 2001. Prinsip Dasar Ilmu Gizi. Gramedia Pustaka Utama. Jakarta.

Kakomole, J. B. 2012. Karakteristik pengeringan biji pala (Myristica fragrans H) menggunakan alat pengering energy surya tipe rak.Skripsi. Jurusan Teknologi Pertanian Fakultas Pertanian, Universitas Sam Ratulangi, Manado.

Taib, G., Said, G., dan Wiraatmadja, S. 1988.Operasi Pengeringan Pada Pengolahan Hasil Pertanian. Mediyatma Sarana Perkasa, Jakarta. 